Manuela Ingaldi ${ }^{l}$

\title{
RÓŻNE PODEJŚCIA DO MODELU LUK
}

Streszczenie: Codziennie korzystamy z różnego rodzaju usług. Przedsiębiorstwa usługowe szukają rozwiązań, jak oferować usługi jak najlepszej jakości oraz jak ta jakość oceniać. W przypadku oceny jakości usług wykorzystuje inne metody i narzędzia niż w przypadku wyrobów. Większość metod opartych jest na różnicy pomiędzy oczekiwaniami klientów oraz ich percepcją gotowej usługi. Różnica ta stanowi jedną z luk modelu jakości usług - modelu luk. Celem artykułu była zestawienie różnych wariantów najczęściej opisywanego w literaturze modelu jakości usług - modelu luk. Niniejszy artykuł stanowi opracowanie teoretyczne, a jego celem pobocznym jest zaznajomienie czytelników z podstawowymi elementami modelu luk.

Słowa kluczowe: usługi, jakość usług, model luk, oczekiwania, percepcja.

\section{Wstęp}

Jakość usług jest definiowana w zupełnie innym sposób niż jakość wyrobów. Jakość wyrobów jest w miarę prosta do zmierzenia. W czasie jego projektowanie określane są różnorodne cechy, które muszą być zachowane w gotowym wyrobie. W przypadku usług i ich niematerialnej formy nie jest to takie proste.

Gilmore zdefiniował usługę jako czynność, proces i wykonanie. Usługi da się również określić szerzej jako działalność gospodarczą wytwarzającą wartość dodaną i zapewniającą korzyści klientom (indywidualnym lub organizacjom). Większość produktów obejmuje dziś pewien element usługi [1]. Według Łańcuckiego jakość usług można określić jako zdolność do ciągłego zaspokajania potrzeb i oczekiwań klientów zewnętrznych i wewnętrznych, uwzględniająca elementy techniczne i funkcjonalne [2].

Według Czubały, Jonasa i Smolenia w usługach głównym źródłem wymagań jest klient-nabywca usługi, a jego zadowolenie odgrywa ważną rolę w ocenie jakości usługi. Usługa ma odpowiednią jakość jeśli jej realizacja spełnia lub przekracza oczekiwania klientów [3]. Według tej definicji klient ocenia usługą na podstawie dwóch kryteriów: jakości technicznej, czyli materialne środki świadczenia usług oraz jakości funkcjonalnej, dotyczy zachowania personelu, jego komunikatywności oraz uzdolnienia. Najbardziej znaczącym czynnikiem satysfakcji klienta jest relacja

\footnotetext{
${ }^{1}$ Dr inż., Department of Production Engineering and Safety, Faculty of Management, Czestochowa University of Technology, Al. Armii Krajowej 19b, 42-200 Częstochowa, Polska, e-mail: manuela.ingaldi@wz.pcz.pl, ORCID ID: 0000-0002-9793-6299
} 
pomiędzy subiektywną oceną poziomu wykonania usługi a oczekiwaniami. Satysfakcja klienta powstaje w sytuacji, gdy subiektywna ocena poziomu jakości usługi jest co najmniej równa oczekiwaniom [4].

Autorzy zajmując się jakości usług stworzyli szereg modeli, które pomagają w jej zrozumieniu oraz wskazują jej najważniejsze elementy. Modele te pomagają także w projektowaniu i doborze metody oceny jakości usług. Pierwszym modelem jakości usług, a także tym najczęściej wykorzystywanym i modyfikowanym, jest model luk stworzony przez Parasuramana, Zeithamla oraz Berry'ego.

Celem artykułu była zestawienie różnych wariantów najczęściej opisywanego w literaturze modelu jakości usług - modelu luk. Niniejszy artykuł stanowi opracowanie teoretyczne, a celem pobocznym jest zaznajomienie czytelników z podstawowymi elementami modelu luk.

\section{PODSTAWOWY MODEL LUK}

Model luk został stworzony w 1985 roku przez Parasuramana, Zeithamla oraz Berry'ego. Jest to najbardziej znany model jakości usług. Założyli oni, że opinia jakości usługi przeprowadzana przez nabywcę usługi wynika z różnicy między jego oczekiwaniami i spostrzeżeniami, które to przyczyniają się do obniżenia jakości świadczonych usług, stało się punktem wyjścia do stworzenia tej koncepcji [5-6]. Jest to jeden z najbardziej znanych i najczęściej wykorzystywanych instrumentów do pomiaru jakości usług, ponieważ zawiera on elementy związane z postrzeganiem usług i przez klienta [7].

W modelu wyróżniono 5 luk powstałych podczas defektów następujących etapów przygotowania i świadczenia usługi. Oznacza to, że podczas trwania całego procesu świadczenia konkretnej usługi mogą pojawiać się pewne rozbieżności między usługodawcą a usługobiorcą. Lukami tymi są [8-9]:

- Luka 1 - różnica między oczekiwaniami klienta, a ocena tych oczekiwań przez kierownictwo.

- Luka 2 - różnica między ocena kierownictwa, a normatywną jakością usługi.

- Luka 3 - różnica między technicznymi normami jakości usług, a faktycznie wykonaną usługą.

- Luka 4 - różnica pomiędzy jakością świadczenia usługi, a informacją, którą uzyskał klient na jej temat.

- Luka 5 - różnica między poziomem spełnienia oczekiwań, a postrzeganiem usługi przez klienta.

Model luk Parasuramana, Zeithamla oraz Berry'ego został przedstawiony na rysunku 1 . 


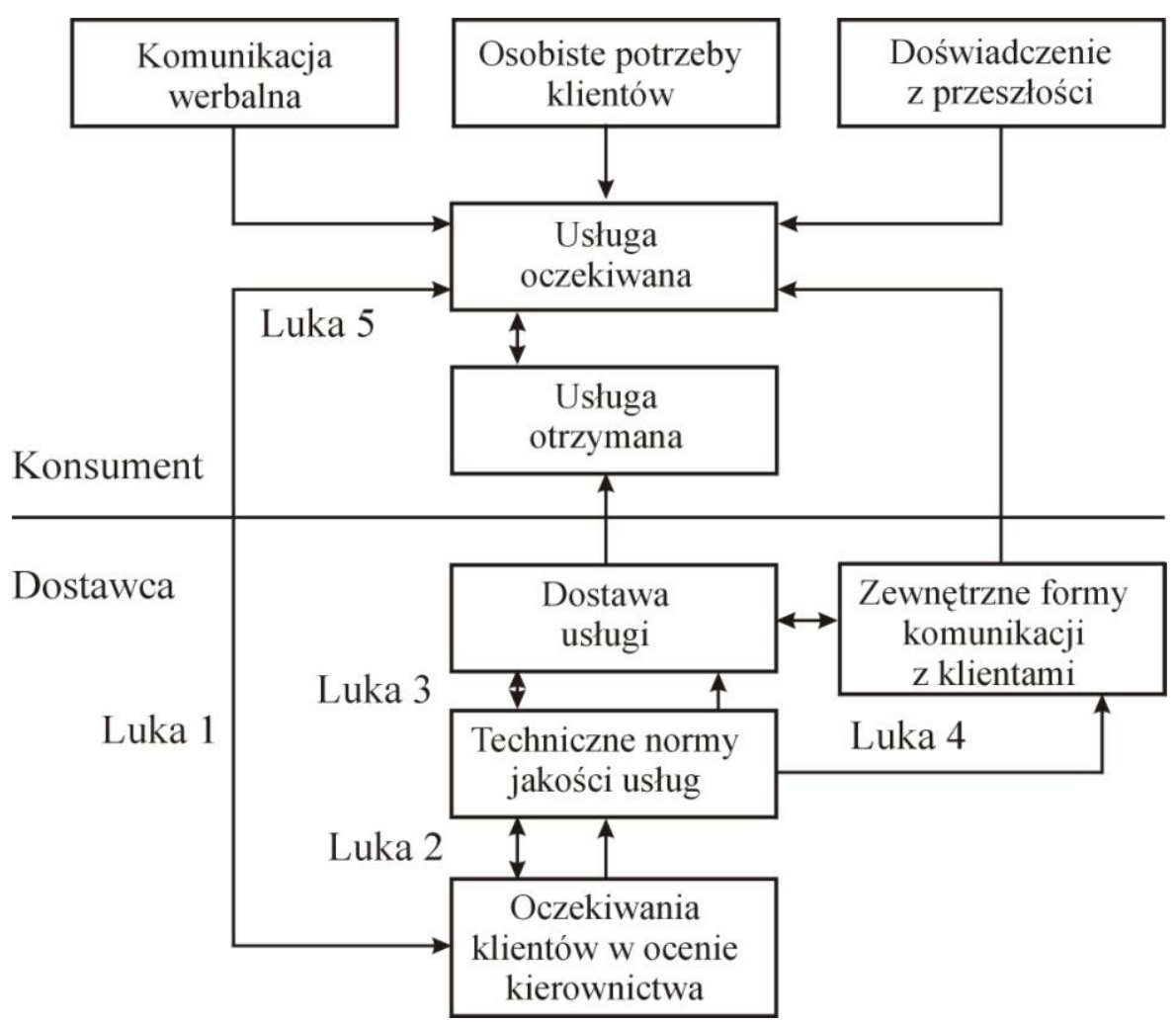

Rys. 1. Model jakości ustug - model luk

Źródło: opracowanie własne na podstawie [5;10-12]

Model luk jest modelem praktycznym i umożliwia nie tylko zrozumieć powód problemu z jakością usług, ale także oszacować braki jakości i wykorzystać właściwe środki zapobiegawcze. Dla przedsiębiorstw świadczących usługi ważne jest, aby w sposób ciągły podejmować działania mające na celu niwelowanie luk i rozbieżności. Najmniej ważna jest natomiast kontrola tych działań.

\section{INNE WERSJE MODELU LUK}

Autorzy modelu luk dokonali kilku jego modyfikacji. Jedna $\mathrm{z}$ ważnych modyfikacji została przedstawiona na rysunku 2 . W modelu tym wskazali, jakie elementy mogą mieć wpływ na poszczególne luki. 


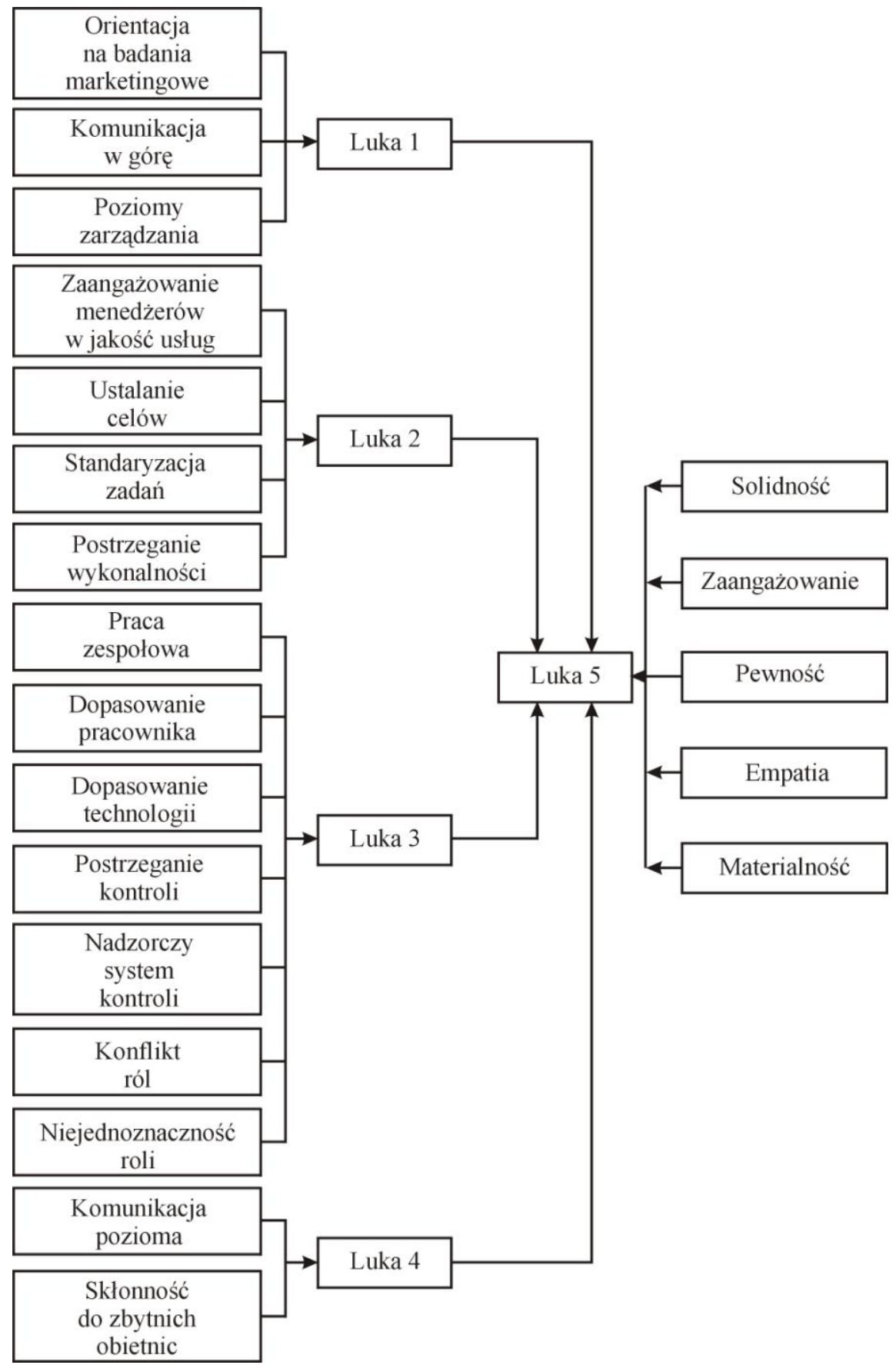

Rys. 2. Rozszerzony model luk

Źródto: opracowanie własne na podstawie [13-14] 
Rozszerzona wersja modelu luk wraz $\mathrm{z}$ barierami została przedstawiona na rysunku 3.

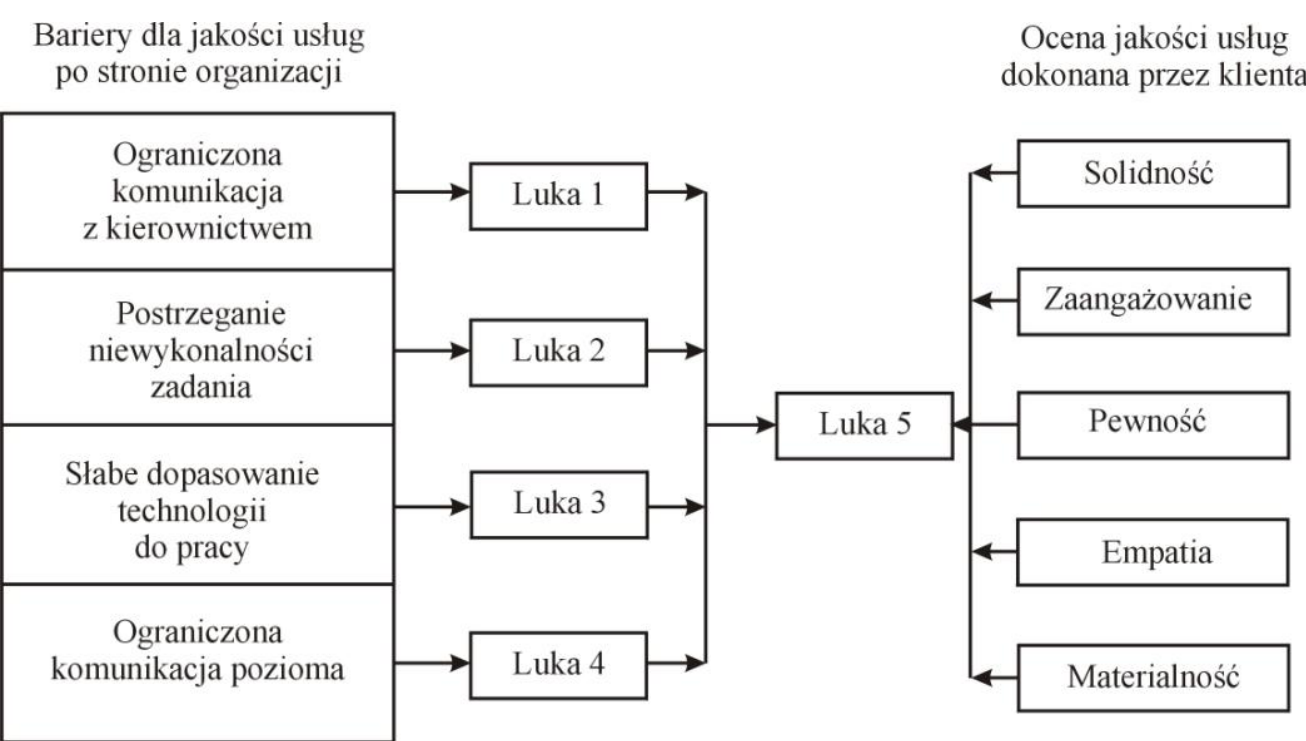

\section{Rys. 3. Rozszerzony model luk II}

Źródto: opracowanie własne na podstawie [14-16]

Model luk jest modelem praktycznym i umożliwia nie tylko zrozumieć powód problemu z jakością usług, ale także oszacować braki jakości i wykorzystać właściwe środki zapobiegawcze. Dla przedsiębiorstw świadczących usługi ważne jest, aby w sposób ciągły podejmować działania mające na celu niwelowanie luk i rozbieżności. Najmniej ważna jest natomiast kontrola tych działań.

Model ten jest uzupełniany lub przekształcany przez innych autorów. Luk i Layton wprowadzili dodatkowe 2 luki do podstawowego modelu luk (rys. 4). Dodatkowymi lukami są [17]:

- Luka 6 - różnica między oczekiwaniami klientów a postrzeganiem oczekiwań klientów przez pracowników. Luka ta jest również bezpośrednio związana z klientami zewnętrznymi. Jeśli pracownicy błędnie rozumieją oczekiwania klientów, to może negatywnie wpłynąć na zadowolenie klientów.

- Luka 7 - różnica między postrzeganiem oczekiwań klientów przez pracowników a oczekiwaniami klientów w ocenie kierownictwa. Można tą lukę zmniejszyć, jeśli istnieje dobra komunikacja między menedżerami a pracownikami, aby rozwiązać problem. 


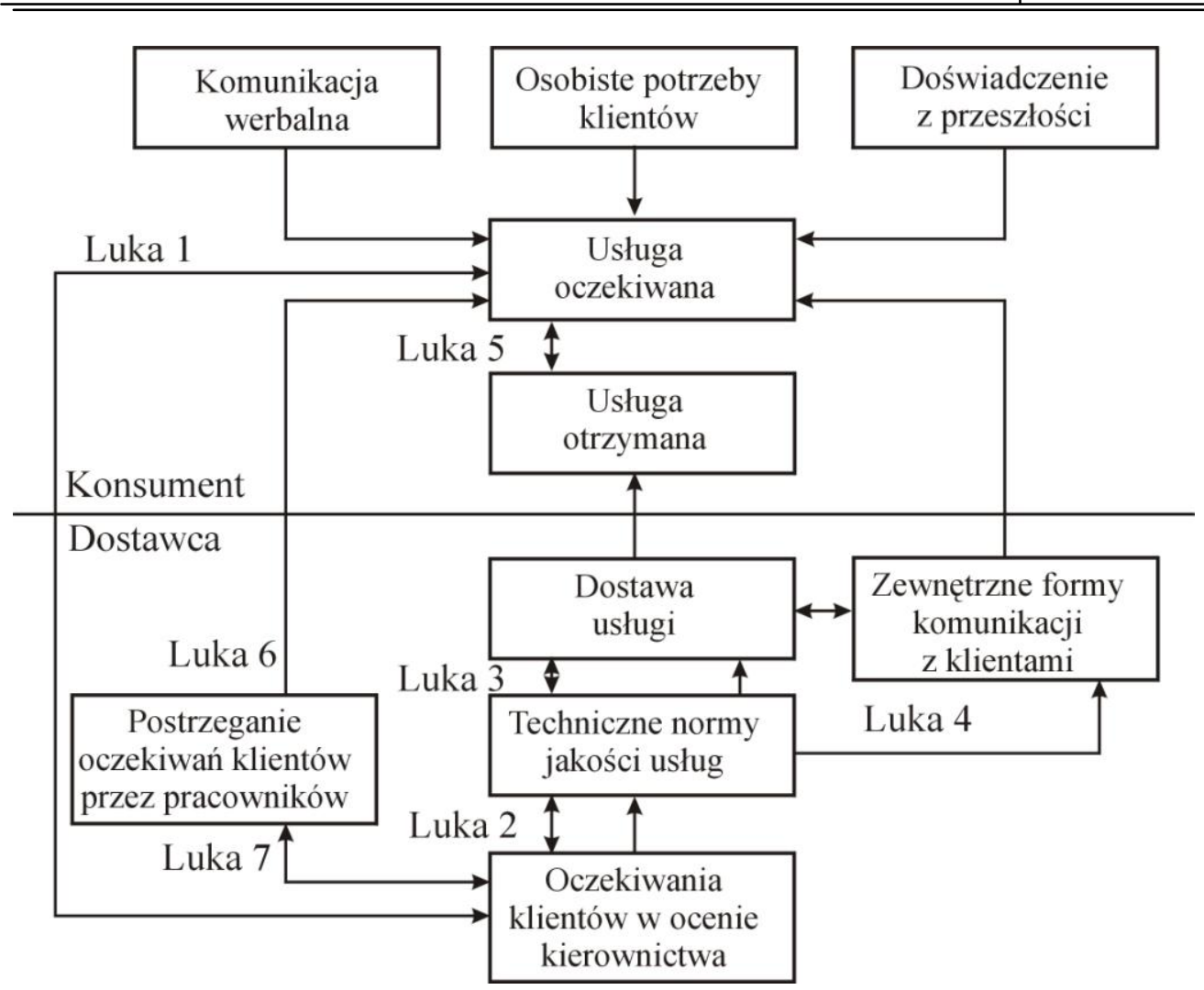

Rys. 4. Model jakości ustug - uzupetniony model luk

Źródto: opracowanie własne na podstawie [17-18]

Natomiast Shahin A., Samea [19] do podstawowego modelu luk dodali jeszcze 7 kolejnych (rys. 5). W modelu tym dodano kilka elementów, między którymi wykryto kolejne luki. Numery niektórych luk uległy zmianie. Liniami przerywanymi zaznaczono nowe, uzupełnione elementy, powiązania i luki. Najbardziej została rozbudowana lewa strona modelu, gdzie uwzględniono postrzegania przez pracowników tego, co klient oczekuje i jak klient postrzega usługę. Uwzględniono także strategię i politykę jakości usług. 


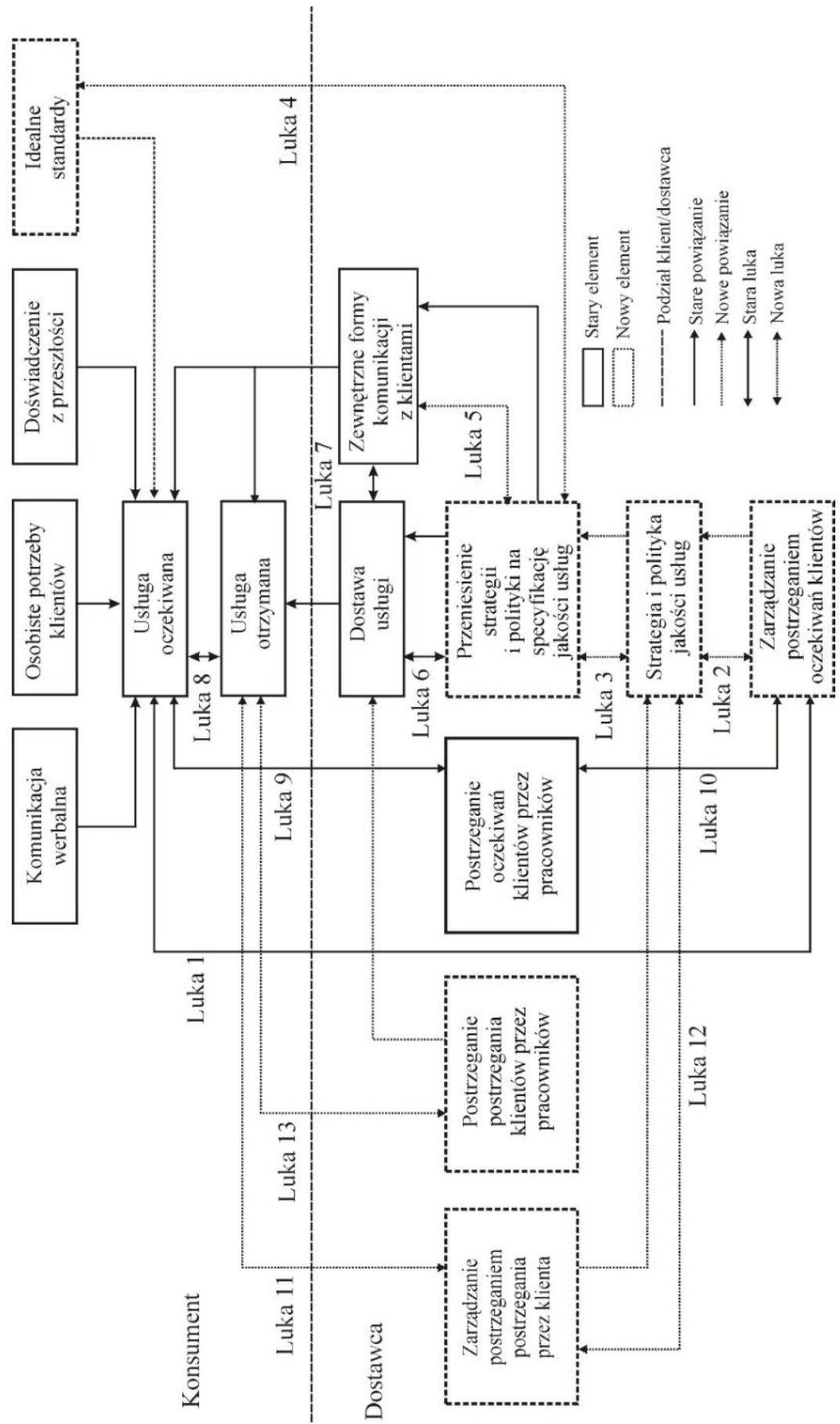

Rys. 5. Rozbudowany model luk

Źródto: opracowanie własne na podstawie [19] 
Istnieje wiele zalet modelu luk, wśród których należy wymienić [11]:

- określa najważniejsze atrybuty jakości usług z perspektywy zarówno klienta, jak i kierownictwa firmy,

- pozwala na zidentyfikowanie przyczyn niskiej oceny jakości danej usługi ze strony usługobiorców,

- określa najważniejsze etapy ewolucji jakości usług rozważane zarówno z perspektywy kierownictwa firmy, jak i usługobiorców,

- pozwala na zidentyfikowanie, a także poznanie zagrożeń (luk), z jakimi może się spotykać firma usługowa, szczególnie w odniesieniu do oczekiwań i spostrzeżeń,

- określa pozytywne skutki, jakie usuniecie tych luk ma dla zarządzania jakością w firmach usługowych,

- pozwala na rozpoznanie źródła zbyt niskiego poziomu jakości określonej usługi od strony klienta;

- wyróżnia najważniejsze momenty ewolucji poziomu usług rozpatrywanych z kierunku kierownika jak i klienta;

- pozwala na rozpoznanie zagrożeń z którymi jest możliwość styczności firmy usługowej w odwołaniu do oczekiwań, a jak również spostrzeżeń;

- ukazuje pozytywne rezultaty, w prowadzeniu jakości w przedsiębiorstwach usługowych, w tedy kiedy usunięte zostaną luki.

W oparciu o model luk powstało jeszcze wiele innych modeli, która opisują jakość usług. Pomagają one w lepszym rozumieniu jakości usług i wyborze metod jej oceny.

\section{Autorki model jakości usług}

$\mathrm{Na}$ podstawie modelu luk oraz innych modeli jakości usług dostępnych w literaturze wybrano najważniejsze elementy i opracowany nowy autorski model jakości usług. Model ten został przedstawiony na rysunku 6. Model oparty jest na podejściu systemowym (systemie produkcyjnym usług).

Jakość usług jest determinowana wieloma elementami (materialność usługi, dostępność, aktualność itd.). Jej poziom, zgodnie z dostępną literaturą i innymi modelami jakości usług, jest wyznaczany przede wszystkim przez dwie składowe: jakość oczekiwana, czy wymagania klientów co do usługi, oraz jakość doświadczona (postrzegana), czyli to, jak klient odbiera gotową usługę i proces jej realizacji. Na obie te składowe ma wpływ wiele elementów. W przypadku jakości oczekiwanej mogą to być np. własne doświadczenie klienta, jego potrzeby, wszechobecne reklamy, wizerunek czy pozycja firmy usługowej na rynki. Jeśli chodzi o jakość doświadczoną, to wśród jej elementów można przebieg procesu świadczenia usługi, jej efekt 
końcowy, zgodność wymagań klienta z jego oczekiwaniami. Jakość usług wpływa na satysfakcję, a w konsekwencji na lojalność klienta. Lojalny klient wróci, ponownie zdecyduje się na usługę, wyda pieniądze, co w efekcie powinno przełożyć się oczywiście na zysk przedsiębiorstwa.

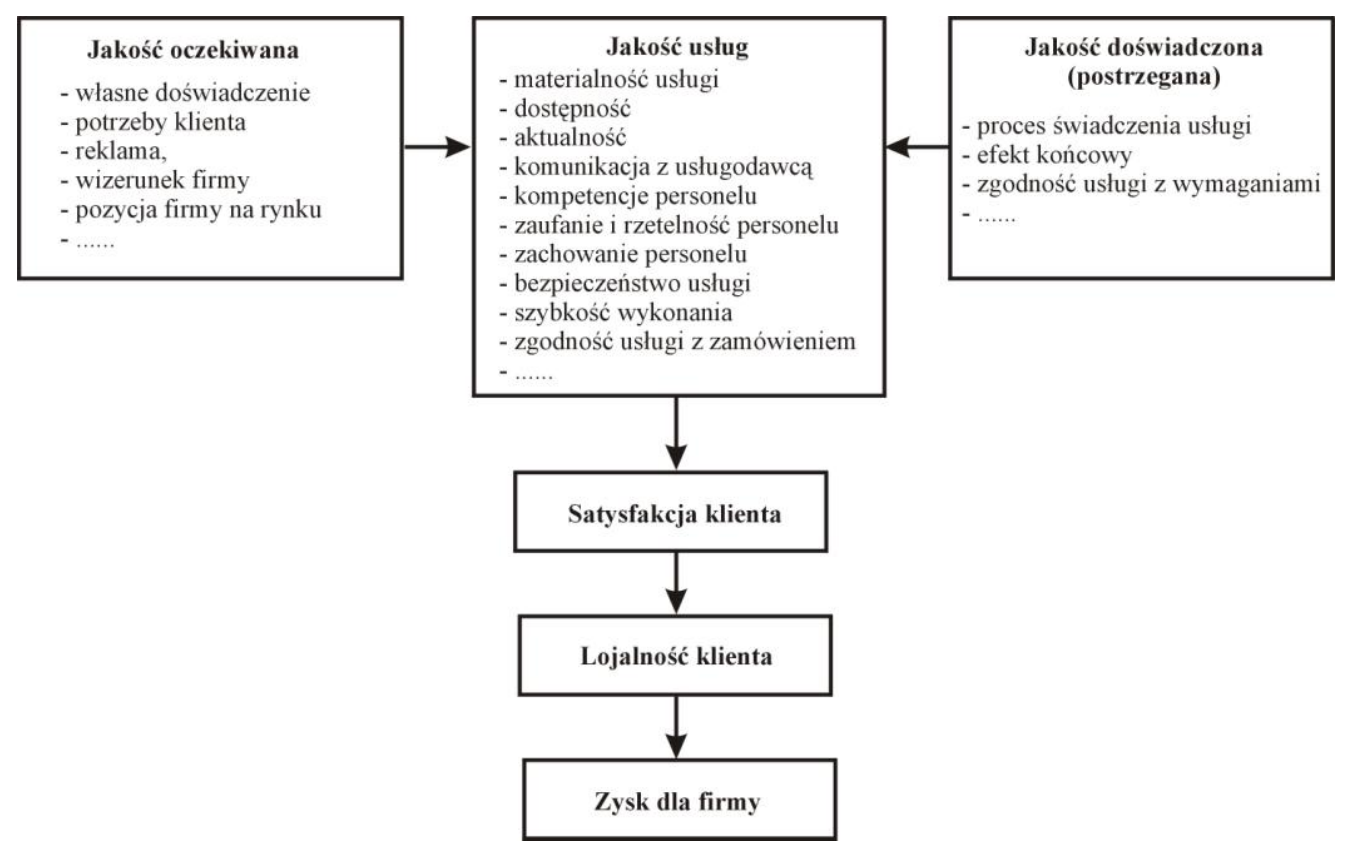

Rys. 6. Autorski model jakości uslug

Źródto: opracowanie własne

\section{PODSUMOWANIE}

Przedstawiony $\mathrm{w}$ artykule model, dzięki opisanym lukom, pozwala na zrozumienie przyczyn niskiej jakości usługi oraz niezadowolenia klientów.

Dzięki poznaniu przyczyn pomaga także we wprowadzeniu środków zaradczych. Model ten powstał przede wszystkim dzięki zastosowaniu metody wnioskowania - indukcji statystycznej, co w tym przypadku oznacza rekonstrukcję kategorii jakości na podstawie danych uzyskanych z badań empirycznych [20].

Wielu autorów inspirowało się modelem luk i powstało wiele innych modelu jakości usług, wśród których należy wspomnieć: Model jakości usług wewnętrznych opracowany przez Frost F.A., Kumar [21], Model jakości usług Grönroosa [22], 
Model poprawy jakości Moore'a czy Zintegrowany model jakości usług 4Q [23]. Również autor niniejszego artykułu pokusił się na opracowanie własnego modelu w oparciu o zdobytą dotąd wiedzę.

\section{Bibliografia}

[1.] Gilmore, A. (2003). Services Marketing and Management. Sage, London.

[2.] Łańcucki, J. (2001). Podstawy kompleksowego zarządzania jakością TQM. Wydawnictwo Akademii Ekonomicznej w Poznaniu, Poznań.

[3.] Czubała, A., Jonas, A., Smoleń T. \& Wiktor J.W. (2012). Marketing usług. Wolters Kluwer Polska Sp. z o.o., Warszawa.

[4.] Bartz, B. (2003). Międzynarodowa certyfikacja jakości ustug. Wydawnictwo WZ PCz, Częstochowa.

[5.] Parasuraman, A., Berry, L.L. \& Zeithaml, V.A. (1991). Refinement and Reassessment of the Servqual Scale. Journal of Retailing, 76(4), 420-450.

[6.] Guglielmetti, R. (2001). L'attenzione al cliente: approccio teorico. [w:] Cappelli, L. \& Renzi, M.F. Management della qualità. CEDAM, Padova.

[7.] Blomer, J., de Ruyter, K. \& Wetzels, M. (1998). Investigating drivers of bank loyalty: the complex relationship between image, service quality and satisfaction. International Journal of Bank Marketing, 16(4), 5-23.

[8.] Wolniak, R. \&Skotnicka-Zasadzień, B. (2009). Wykorzystanie metody Servqual do badania jakości ustug $w$ administracji samorzadowej. Wydawnictwo Politechniki Śląskiej, Gliwice.

[9.] Urbaniak, A.M. (2013). Zastosowanie metody Servqual do oceny jakości ustug rekreacyjnych. Zeszyty Naukowe Uczelni Vistula, 32, 29-38.

[10.] Parasurman, A., Zeithaml, V.A. \& Berry, L.L. (1985). A conceptual model of service quality and its implications for the future research. Journal of Marketing, 49(4), 41-50.

[11.] Stoma, M. (2012). Modele i metody pomiaru jakości ustug. Q\&R Polska Sp. z o.o., Lublin.

[12.] Bielawa, A. (2011). Przegląd najważniejszych modeli zarządzania jakościa ustug. Studia i Prace Wydziału Nauk Ekonomicznych I Zarządzania, 24, Gospodarka, Zarządzanie, Środowisko, 7-23.

[13.] Zeithaml, V.A., Berry, L.L. \& Parasuraman, A. (1988). Communication and control processes in the delivery of service quality. Journal of Marketing, 52(2), 35-48.

[14.] Seth, N., Deshmukh, S.G. \& Vrat, P. (2005). Service quality models: a review. International Journal of Quality \& Reliability Management, 22(9), 913-949.

[15.] Parasuraman, A. (2004). Assessing and improving service performance for maximum impact: insights from a two-decade-long research journey. Performance Measurement and Metrix, 5(2), 45-52.

[16.] Skikiewicz, R. (2010). Jakość ustug bankowych a konkurencyjność banków. Rozprawa doktorska. Uniwersytet Ekonomiczny w Poznaniu, Wydział Zarządzania, Poznań.

[17.] Luk, S.T.K. \& Layton, R. (2002). Perception Gaps in Customer Expectations: Managers Versus Service Providers and Customers. The Service Industries Journal, 22(2), 109-128.

[18.] Na, L. (2010). Service quality and customer satisfaction in the hotel industry. Praca magisterska Politecnico Di Milano, Facoltà di Ingegneria dei Sistemi, Milan, 
(https://www.politesi.polimi.it/bitstream/10589/13105/1/2010_10_Le.pdf

(odczyt 15.11.18).

[19.] Shahin, A. \& Samea, M. (2010). Developing the Models of Service Quality Gaps: A Critical Discussion. Business Management and Strategy, 1(1): E2.

[20.] Chabiera, J. (2000). Zarządzanie jakościa - poradnik menedżera. Centrum Informacji Menedżera, Warszawa.

[21.] Frost, F.A., Kumar, M. (2000). INTSERVQUAL: an internal adaptation of the GAP model in a large service organization. Journal of Services Marketing, Vol. 14, Iss. 5, s. 358-377.

[22.] Grönroos, C. (1978). A Service Oriented Approach to Marketing of Service. European Journal of Marketing, vol. 12, nr 8, s. 588-601.

[23.] Gummesson, E. (1993). Quality Management in Service Organizations. ISQA, New York.

[24.] Moore, C.D. (1987). Outclass the Competition with Service Distinction. Mortgage Bank, vol. 47 , iss. 11.

\title{
DIFFERENT APPROACHES TO THE GAP MODEL
}

\begin{abstract}
Every day we use various types of services. Service companies are looking for solutions on how to offer services with the best quality and how to assess this quality. When assessing the quality of services, different methods and tools than in case of products are used. Most methods are based on the difference between customers' expectations and their perception of the ready service. This difference is one of the gaps in the service quality model - the gap model. The aim of the paper was to compile various variants of the service quality model most frequently described in the literature - the gap model. This paper is a theoretical study and its secondary goal is to familiarize readers with the basic elements of the gap model.
\end{abstract}

Key words: services, quality of services, gap model, expectations, perception.

Data przestania publikacji do Redakcji: 17.09.2019

Data akceptacji publikacji przez Redakcję: 22.11.2019

DOI: 10.30657/qpi.2019.11.06 